\title{
Isolation and identification of ectoparasites in single humped camels (Camelus dromedarius) of Cholistan area, Pakistan
}

\author{
M.F. Qamar', M.M. Ayaz ${ }^{2,3 *}$ and M.M. Nazir² \\ ${ }^{1}$ Department of Parasitology, College of Veterinary and Animal Sciences (CVAS), Jhang, Sub-Campus Lahore-Pakistan, \\ ${ }^{2}$ Department of Pathobiology, Faculty of Veterinary Sciences, Bahauddin Zakariya University, Multan, Pakistan \\ ${ }^{3}$ Department of Parasitology, Faculty of Veterinary Sciences, Cholistan University of Veterinary and Animal Sciences, \\ Bahawalpur, Pakistan, *Correspondence author: mazharayaz@bzu.edu.pk
}

(Received February 2, 2018; Accepted June 27, 2018)

\begin{abstract}
Thirty herds comprising four hundred and fifty camels (Camelus dromedarius ) ranging from 5 months to 17 years of age were subjected to external examination of ectoparasites (ticks, mange mites and flies) during November 2010 to July 2011 at Cholistan, Bahawalpur, Pakistan. An overall prevalence of Ectoparasites was 55.55\%. Ticks were the most frequent ectoparasites harboring on dromedaries. The ticks in order of their infestations were; Rhipicephalus spp (28.95\%) Hyalomma dromedarii (26.48\%), Dermacentor spp (18.29\%) H. anatolicum (12.47\%), H. marginatum (6.69\%), Ornithodoros spp. (4.89\%) and Amblyomma variegatum (2.20\%). The Sarcoptes scabiei var. cameli (42.22\%) was identified as most dominant mange mite. $40.88 \%$ camels were infested with two species of dipterans i.e.; Chrysomyia spp. (10\%) and Wohlfahrtia magnifica $(16.67 \%)$ which are most frequently causing preputial and vaginal myiasis. Cephalopina titilator fly (1.11\%) was found to cause camel nasal myiasis. The district wise prevalence was as Rahim Yar Khan (60.87\%), followed by Bahawalnagar (49.75\%) and Bahawalpur (41.05\%). The tick load per animal was higher during summer especially in July (64.52\%) followed by the lowest ticks load during December (25.58\%).The infestation of ectoparasites was higher (69.53\%) in camels ranging the age from 5-7 year however the lowest infestation (23.08\%) was noted in camels less than one year of age.
\end{abstract}

Keywords: Ectoparasites, Cholistan desert, Camel, Hyalomma spp., Pakistan

Available online at http://www.vetmedmosul.com

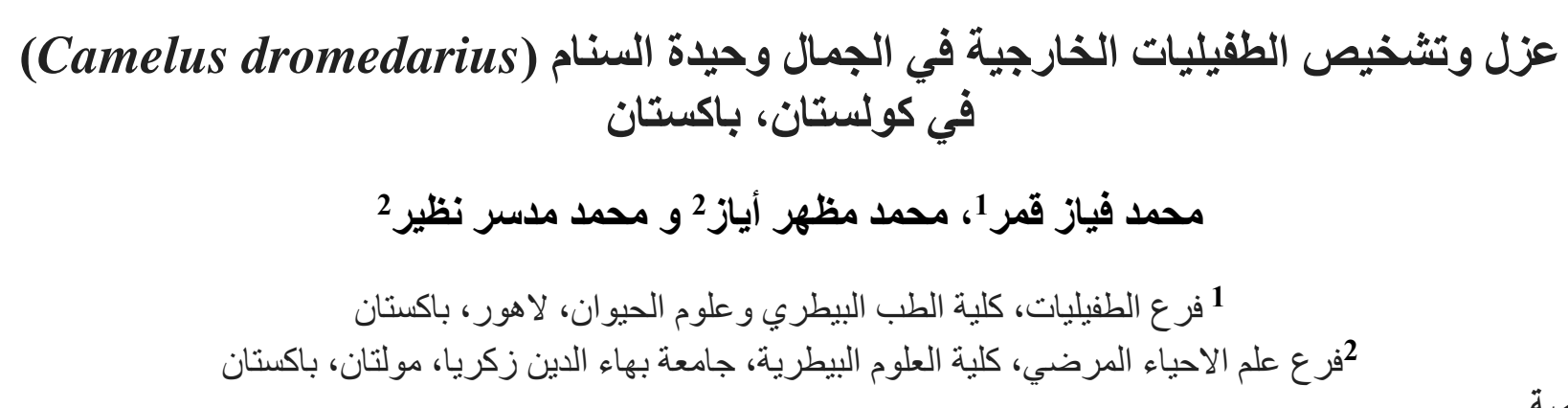

تم فحص 450 جملا من ثُلاثون قطيعا من الجمال وحيدة السنام

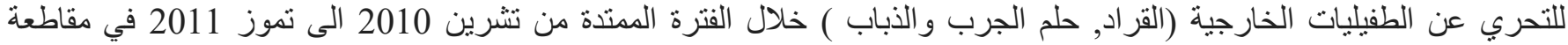

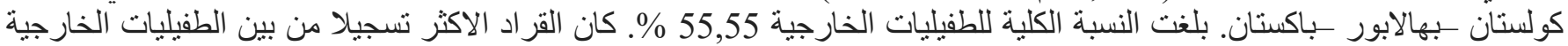

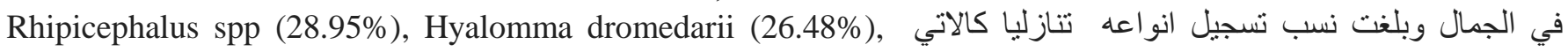
و, Dermacentor spp (18.29\%), H. anatolicum (12.47\%), H. marginatum (6.69\%), Ornithodoros spp (4.89\%

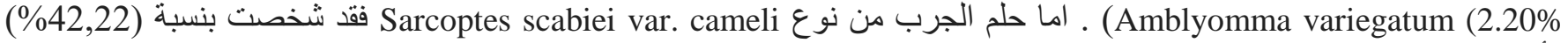
كأكثر انواع الحلم تو اجدا. سجلت نسبة خمج بنسبة وبنسبة (10\%) ونوع Wohlfahrtia magnifica بنسبة (16,67\%) وهي الاغلب الني تؤدي الى النغف في القلف والمهبل. اما ذبابة 


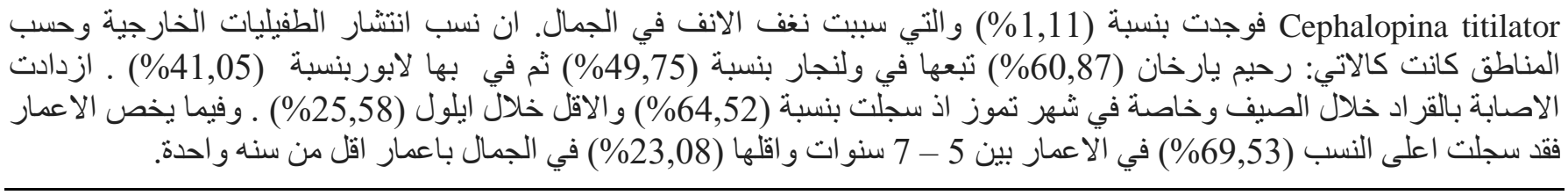

\section{Introduction}

In Cholistan desert, camel is the best adopted animal, a hope of life for nomads. It provides milk, meat, leather and is used for transportation, entertainment like dancing and racing (1). The camel is capable of enduring thirst and hunger for days and plays a pivotal role in the socioeconomic uplift of the community of cholistan desert (2). Many pastoral groups and communities are solely depending on camels in diverse ecozones throughout the world, the nomads are depending on camels for their livelihood (5) in the wide deserted less rainfall area makes the life scare in drinkable sweat water. Sweet water in Cholistan is collected in natural depressions or manmade ponds called "Tobas" during the rainy season (6). There are 598 Tobas in Cholistan, which are primary sources of water for survival and for Livestock as well as human beings (7). In cholistan, life is difficult but it still nurtures certain ectoparasites which are best adapted to harsh season. Ticks are one of the most important ectoparasites of camel. It serves as a vector to numerous pathogens including protozoans (Trypnosomiasis), rickettsiae (ehrlichiosis), viruses (e.g., Foot and mouth Disease), bacteria (e.g., Pasteurell spp, Brucella, Listeria spp and Staphylococcus) and spirochetes (11). One of the drawback of Tick infestations is not only it lower the production of animals but can also plays a vector role (8). These diseases are mostly confined to tropical and subtropical countries especially India, Pakistan and Bangladesh, where climatic conditions are conducive for the growth and development of many tick species (9). In these countries, situation is further deteriorated due to lack of proper management practices (10). Blood is a vital fluid for host as well as for the ticks; blood loss causes functional impairment in the camels and even heavily infested camels are retarded, thin, weak and stunted. Productions factors like milk yield are greatly reduced. Economic losses up to $20-30 \%$ are due to depreciation of the value of skins and hides (11-13). Ghosh et al. (9) have reviewed effective tick control strategies and methods in camels (14). Other common skin problems in camels are due to ecto-parasites like sarcoptic mange mainly caused by Sarcoptes scabiei var. cameli; a threatening and serious health hazard in Cholistan. Mange lesions vary with season, region nutritional status, age and other predisposing factors (15). Transmission of agents of disease is reported by direct contact or through infected fomites (trees, blankets and baggage). Myiasis in camels is reported worldwide (16). Flea (order Siphonaptera) infestations are also described as a major parasitic problem of animals (17). Although reports on flea infestations in camels are frequent and they are unusual on livestock farms (18). The manage caused by Psoroptes cameli has mild and superficial infestation on skin with varying degrees of pruritis in camels. The present investigation was designed to record the prevalence and infestation of ectoparasites like ticks, mange and myiasis infestation in one humped camels (Camelus dromedarius) in three various agro-ecological sites including Rahim Yar Khan, Bahawalnagar and Bahawalpur of Cholistan desert situated in Pakistan.

\section{Materials and methods}

\section{Geo-location of study}

The research was carried out in three agro-ecological sites including Rahim Yar Khan, Bahawalnagar and Bahawalpur of Cholistan desert located in Pakistan at latitudes $27^{\circ} 42^{\prime}$ and $29^{\circ} 45$ North and longitudes $69^{\circ} 52^{\prime}$ and $75^{\circ} 24^{\prime}$ East at $112 \mathrm{~m}$ above the sea level.

\section{Meteorological study}

The climate of this area is arid, harsh, hot subtropical. In monsoonal the average annual rainfall is $180 \mathrm{~mm}$ that is very inconsistent both in quantity and duration with prolonged droughts that are common after every 10 years interval causing famine and drought. The mean annual temperature is $28.33^{\circ} \mathrm{C}$ except in June being the hottest exceeds $45^{\circ} \mathrm{C}(2)$.

\section{The selection of study animals}

This study was sprawled on 450 clinically healthy onehumped camels (Camelus dromedarius) ranging from 5 months age to 17 years of age. All the animals were raised by local farmers and usual fed low quality diets contained mainly straw, barley, shrubs and wilted grass spread in the area. The animals under study were examined for the presence of ecto-parasites from November 2010 to July 2011 irrespective of their breed, sex and age. Thirty tobas (10 from each district) were selected on the basis of simple proportionate sampling method as described by Thrusfield, 1995 and the minimum distance between each toba was 10 $\mathrm{km}$ approximately. The data was collected on the prescribed Performa containing information about the daily aggregation of camels on drinking spot, selection of shrubs and routes for usual travel. The samples of ectoparasites 
were brought to the laboratories of Parasitology, Department of Pathobiology, Faculty of Veterinary Sciences, Bahauddin Zakariya University, Multan, The samples of shrubs were brought to the parasitology laboratory, College of Veterinary and Animal Sciences, CVAS, UVAS, Jhang campus, Pakistan.

\section{Collection and identification procedures of ectoparasites Collection of ectoparasites}

Ticks were collected (without damage to their mouth parts with forceps) from infested camels (19). The collected ticks were stored and preserved in glass vessel containing $70 \%$ alcohol and 5\% glycerol. Tick collection was performed during dusk and dawn from the skin of the animals. The containers were labeled individually with the date and place of collection. The information were collected and data was recorded on the prescribed Performa included the predilection site of the ticks (head, neck, shoulder, back, udder, urogenital area, flanks, front and hind legs), ethno veterinary remedies adopted by the camel farmers and usual shrubs adopted for eating by the camels and frequency of camels aggregation.

Deep skin scraping was performed in affected animals with the help of scalpel blade after the disinfection of the area for the presence of mange mite infestation (20). The mange mites from the different body regions including; head, neck, flanks, front and hind legs, and belly were placed separately in white blotting paper (21).

\section{Identification of ectoparasites}

The collected ectoparasites (ticks, mange mite and flies) were identified accordingly as Wall and Shearer (21) and Walker et al. (22). The skin and hide of all camels under study were thoroughly examined for the presence of ectoparasite lesions especially the area on face, neck, inguinal region, sides of the body and around the tail. The confirmation of mange mite was concluded by microscopic examinations of skin scrapings after $10 \% \mathrm{KOH}$ digestion method on the basis of morphological characteristics as described (23-25).

\section{Collection of Litter for the presence of larvae}

The Litter samples from a depth of $4,8,12$, and $16 \mathrm{~cm}$ were collected from the fence areas of infested camels to investigate the presence of larval stages of the ectoparasites, if any.

\section{Statistical Analysis}

The data collected for the prevalence of ectoparasites in camels were analyzed by using Interceded STATA (Version 7) software. The Chi-square $\left(\mathrm{X}^{2}\right)$ test was used to assess differences in the prevalence and frequency of ectoparasites among study areas, sex, month of the year and age groups. In all cases, 95\% confidence intervals and
$P<0.05$ were set for significance (26).

\section{Results and discussion}

\section{Over all prevalence of ectoparasites}

Overall prevalence of ectoparasites including ticks, mange and myiasis was recorded $55.56 \%$ during the current study (Table 1).

Table 1: Comparison of mean prevalence of ectoparasites in camels at various tobas of Cholistan

\begin{tabular}{|c|c|c|c|}
\hline Study Area & $\begin{array}{c}\text { No. of } \\
\text { camels } \\
\text { Examined }\end{array}$ & $\begin{array}{c}\text { No. of } \\
\text { infested } \\
\text { camels }\end{array}$ & $\begin{array}{c}\text { Over all } \% \\
\text { of } \\
\text { prevalence } \\
\text { of infected } \\
\text { animals on } \\
\text { tobas }\end{array}$ \\
\hline Bahu wala Toba & 12 & 8 & 66.67 \\
\hline Bai Lah Wala Tibba & 20 & 9 & 45.00 \\
\hline Bhai Khan & 14 & 8 & 57.14 \\
\hline Bhuddi Wali Khui & 21 & 9 & 42.86 \\
\hline Bijnot Fort & 11 & 7 & 63.64 \\
\hline Channan Pir Wala & 15 & 8 & 53.33 \\
\hline Cheepan Wala Toba & 16 & 9 & 56.25 \\
\hline Derawar Fort & 14 & 7 & 50.00 \\
\hline Din Garh Fort & 17 & 8 & 47.06 \\
\hline Dosste Wala Toba & 19 & 9 & 47.37 \\
\hline Gadhen Wala Toba & 21 & 15 & 71.43 \\
\hline Islam Gargh & 16 & 6 & 37.50 \\
\hline Jam Sar, & 11 & 8 & 72.73 \\
\hline Khaitran Wala Toba & 12 & 9 & 75.00 \\
\hline Khanu wala toba & 12 & 7 & 58.33 \\
\hline Khiwtal Wala Toba & 19 & 11 & 57.89 \\
\hline Khokhran Wala Toba1 & 15 & 10 & 66.67 \\
\hline Khokhran Wala Toba2 & 13 & 6 & 46.15 \\
\hline Lunja wala toba & 18 & 7 & 38.89 \\
\hline Masu Wala Toba & 16 & 8 & 50.00 \\
\hline Moujgarh Fort & 9 & 6 & 66.67 \\
\hline Noor Sar toba, & 12 & 8 & 66.67 \\
\hline Dolu toba & 13 & 6 & 46.15 \\
\hline Noora wala toba & 18 & 12 & 66.67 \\
\hline Roda Wala Toba & 15 & 9 & 60.00 \\
\hline Sar wala toba & 16 & 8 & 50.00 \\
\hline Shaheedan Wala Toba & 14 & 6 & 42.86 \\
\hline Sohaib Wala. & 13 & 8 & 61.54 \\
\hline Sulleh Wala Toba & 13 & 7 & 53.85 \\
\hline Taraway Wala Toba, & 15 & 11 & 73.33 \\
\hline Total & 450 & 250 & 55.56 \\
\hline
\end{tabular}

$\mathrm{X} 2=21.10, \mathrm{P}-$ value $=0.855$ (No significant variation was observed in the prevalence of ectoparasites among various study sites except higher prevalence of ectoparasites infestation in toba number 11,13 and 14) as in Graph 1. 


\section{Identification of the ticks}

A total of 7720 ticks were recovered from 450 infested animals. Seven species of ticks in order of their prevalence were identified as Rhipicephalus spp. ( $R$. pulchellus), Dermacentor spp. Hyalomma spp. (H. anatolicum, H.marginatum, H.dromedarii), Ornithodoros and Amblyoma (A. varigatum). A total of 2235 (28.95\%) of Rhipicephalus spp., 2045 (26.48\%) of Hyalomma dromedarii, 1412 (18.29\%) of Dermacentor sp, 963 (12.47\%) of Hyalomma anatolicum, 517 (6.69\%) of Hyalomma marginatum, 378 (4.89\%) of Ornithodoros and $170(2.20 \%)$ of Amblyomma variegatum were observed during the study. Dinka et al. (27) reported three tick species; Amblyomma gemma (15.10\%), Hyalomma dromedarii (15.36\%) and Rhipicephalus pulchellus $(27.86 \%)$ from Nigeria (27) were reported while in Iran especially in Northeast Province of Khorasan the ticks like Hyalomma dromedarri (90.7\%) is a dominant species (34) that is in consistent with our study. It indicates that there is a wide range of ticks' species that causes manifestation in camel in different parts of the world $(28,29)$ but Hyalomma dromedarii is present in African and Asian countries equally in Iran also.

Three species of flies were found infesting one hundred and eighty four (40.88\%) camels i.e; Chrysomyia spp. (10\%), Wohlfahrtia magnifica (16.67\%) and Cephalopina titilator fly $(1.11 \%)$ was found to cause nasal myiasis in camel while other causes vaginal and preputial myiasis. Oryan, et al. (31) reported contrast results for Nasal myiasis Seven hundred and seventy one camels $(58.1 \%)$ were infested with this larvae and the rate of infestation was significantly greater in the colder months (69.8\%) compared to those of warmer months $(36.2 \%)$. In male camels the ectoparasitic infestation was $49.55 \%$ as compared to those of the female camels $(57.2 \%)$. The prevalence rate was lower in camels younger than 1 year old $(23.08 \%)$ compared to those of 3-5 (55.26\%) and over $5-7$ years old $(69.53 \%)$ also reported by Tesfahyet and Onu (30). A total of thirty tobas (10 from each district) were investigated in which gleaned that all tobas were found to be infested due to visit of infested camels. The highest prevalence as described in Table 1, 2, 3 and 4, the $75 \%$ was observed at Khitran wala toba, while the lowest $37.5 \%$ at Toba Islam Gargh. The district wise prevalence revealed highest incidence at Rahim Yar Khan (60.87\%), followed by Bahawalnagar (49.75\%) and Bahawalpur $(41.05 \%)$. The present study reports that the prevalence of ectoparasites in relation to different study sites and sex $(\mathrm{P}>0.05)$ in not significantly different. This shows that the management and environmental conditions for the propagation of ectoparasites is almost similar throughout the Cholistan desert. However, highly significant difference $(\mathrm{P}>0.05)$ was observed statistically among various age groups as well as during different months of the year. It indicates that immunity titer varies during different ages and climatic conditions of the different months play vital role for the ectoparasites infestation. Regarding the age groups the prevalence was higher $(69.53 \%)$ in animals between 5 to 7 years of age while lowest was observed in less than one year of age (23.08\%) as shown in Figure 1, 2, 3 and 4 and also in Graph 4. Statistically there was no effect of sex $(\mathrm{P}>0.05)$ on prevalence and severity of ectoparasites, however, high humidity and temperature have significant role in the propagation of diseases. During summer highest numbers of infective larvae were found that are directly responsible for the occurrence of disease. Demodectic mange was diagnosed in $58.2 \%$ of camels ranged in 5-10 years old \& $16.4 \%$ of camels more than 10 years old and $25.4 \%$ in camels less than 5 years old which indicate the high incidence in camels aged in 5-10 years (31). Our results are in agreement with Hussain et al. (32) but they have studied only mange while we have studied collectively all the ectoparasites including ticks, fleas, flies, mange and mite infestation in camels (31). Lawal et al. (33) reported $91.26 \%$ ticks, $4.63 \%$ flies, $3.54 \%$ mites and $0.55 \%$ lice respectively (32). The prevalence of infestation from September to March that is identical to the cold seasons (autumn and winter) in this country was significantly higher $(69.9 \%)$ than warm seasons $(36.0 \%)(P<0.05)$. The rate of infestation was significantly higher in females (57.2\%) compared to those of male animals $(49.55 \%)(P<0.05)$. The prevalence of infestation was also significantly higher in young animals of age ranging 3-5 years $(55.26 \%)$ and older than 5-7 years of age groups (69.53\%) compared to those of less than 1-3 years old animals $(\mathrm{P}<0.05)$. The tick load per animal was found higher during summer months (May \& July) than during winter months (February). The lowest ticks load was gleaned during December $(25.58 \%)$, whereas the highest was recorded in July (64.52\%) (33). The reason might be frequent huddling of the winter months and higher humidity levels and perspiration of animals during warmer months. The contaminated clothing used may be another factor.

Table 2: Sex wise Comparison of mean prevalence of ectoparasites on camels

\begin{tabular}{lccc}
\hline $\begin{array}{l}\text { Sex wise } \\
\text { distribution }\end{array}$ & $\begin{array}{c}\text { No. of } \\
\text { Examined } \\
\text { camels }\end{array}$ & $\begin{array}{c}\text { No. of } \\
\text { infested } \\
\text { camels }\end{array}$ & $\begin{array}{c}\text { \% prevalence of } \\
\text { ectoparasites on } \\
\text { camels }\end{array}$ \\
\hline Male & 111 & 55 & 49.55 \\
Female & 339 & 195 & 57.52 \\
\hline Total & 450 & 250 & 55.56 \\
\hline
\end{tabular}

$\mathrm{X} 2=0.1423, \mathrm{P}-$ value $=0.9288$ (No significant difference was observed statistically in the prevalence of ectoparasites between different sex groups) however female camels were infested higher up to $57.52 \%$ as shown in Graph 2. 
Table 3: Month wise Comparison of mean prevalence of ectoparasites in camels

\begin{tabular}{lccc}
\hline Months & $\begin{array}{c}\text { No. of } \\
\text { camels } \\
\text { Examined }\end{array}$ & $\begin{array}{c}\text { No. of } \\
\text { infested } \\
\text { camels }\end{array}$ & $\begin{array}{c}\text { \% prevalence of } \\
\text { ectoparasitic } \\
\text { infected animals }\end{array}$ \\
\hline November,2010 & 55 & 25 & 45.45 \\
December,2010 & 43 & 11 & 25.58 \\
January,2011 & 65 & 39 & 60.00 \\
February,2011 & 78 & 48 & 61.54 \\
March,2011 & 25 & 14 & 56.00 \\
April,2011 & 48 & 29 & 60.42 \\
May,2011 & 35 & 22 & 62.86 \\
June,201 & 39 & 22 & 56.41 \\
July,2011 & 62 & 40 & 64.52 \\
\hline Total & 450 & 250 & 55.56 \\
\hline X2
\end{tabular}

$\mathrm{X} 2=22.81, \mathrm{P}-$ value $=0.004$ (Significant difference was observed in the prevalence of ectoparasites during different months of the year but the most activity of the ectoparasites were recorded during February, May and July months).

Table 4: Age wise Comparison of prevalence of ectoparasites in camels

\begin{tabular}{|c|c|c|c|}
\hline Age & $\begin{array}{c}\text { No. } \\
\text { camels } \\
\text { Examined }\end{array}$ & $\begin{array}{l}\text { No. of } \\
\text { infested } \\
\text { camels }\end{array}$ & $\begin{array}{c}\text { Over all \% } \\
\text { prevalence } \\
\text { of infected } \\
\text { animals }\end{array}$ \\
\hline Less than 1 year & 26 & 6 & \\
\hline Bet & 99 & 8 & \\
\hline Bet & 152 & 4 & \\
\hline & 128 & & \\
\hline & 45 & & \\
\hline Total & 450 & 250 & \\
\hline \multicolumn{4}{|c|}{$\begin{array}{l}\mathrm{X} 2=23.629, \mathrm{P}-\text { value }=0.005 \text { (Highly significant } \\
\text { difference was observed in the prevalence of ectoparasites } \\
\text { among different age groups but the higher prevalence was } \\
\text { observed between the age groups from 3-7 years) as shown } \\
\text { in Graph 3. }\end{array}$} \\
\hline \multicolumn{4}{|c|}{$\begin{array}{l}\text { In conclusion, the major tick species is Rhipicephalus } \\
\text { spp. Infestations appeared to be associated with adverse } \\
\text { environmental and managemental conditions present in the } \\
\text { study area. In cholistan camels acquire one or more } \\
\text { ectoparasites (Ticks and Mange Infestation) in almost all } \\
\text { seasons. The most workable plan adopted by the nomads is } \\
\text { the manual detachment of ticks from skin. Use of tick } \\
\text { repellents on skin or clothing, as directed on the product } \\
\text { label, is another important preventive measure for people } \\
\text { who enter tick-infested habitats along with ethnoveterinary } \\
\text { formulations. }\end{array}$} \\
\hline
\end{tabular}

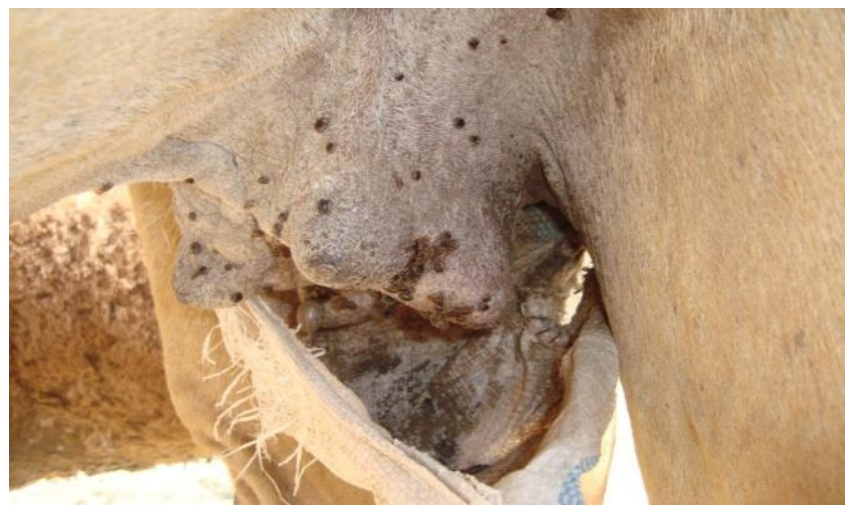

Figure 1: presence /attachment of Ticks at the udder region of a Female Camel.

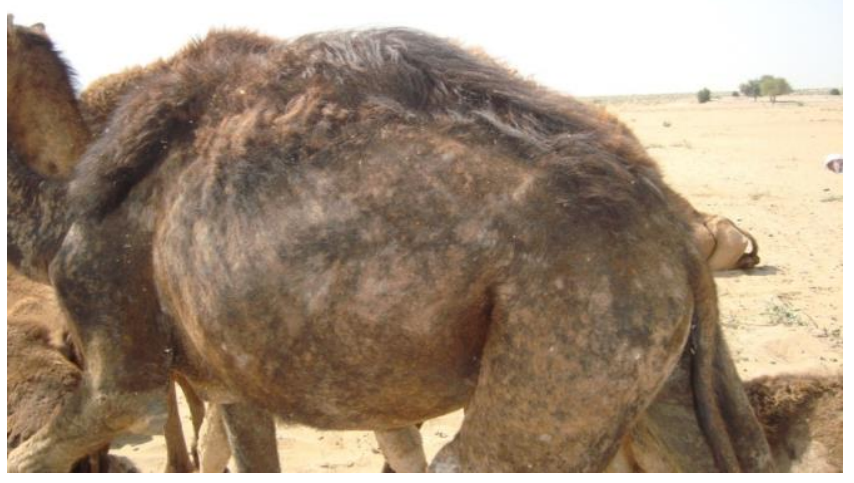

Figure 2: Skin patches due to Mange infestation on the body of a Camel as reservoir.

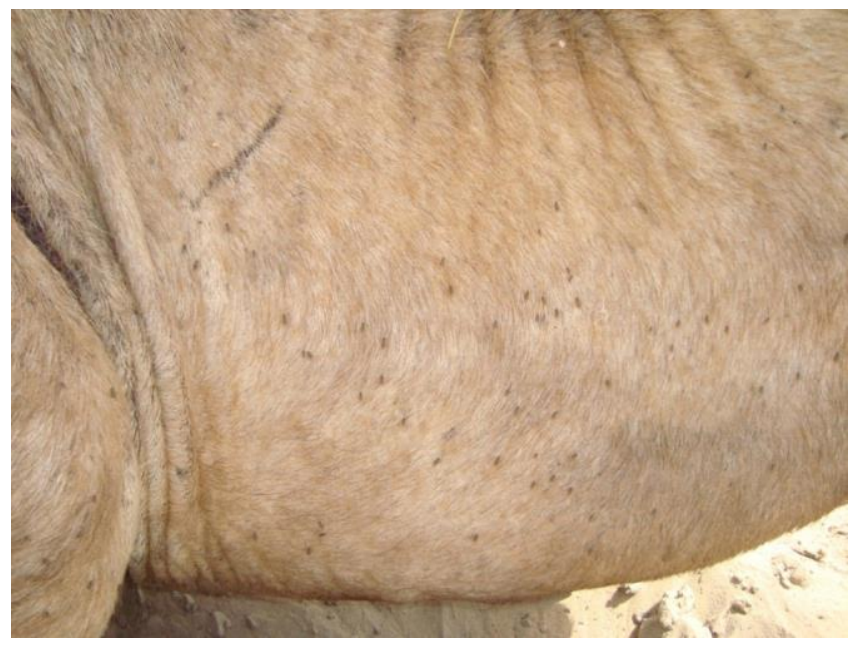

Figure 3: Ticks infestation on the abdomen wall of a Camel; a common site of contact. 


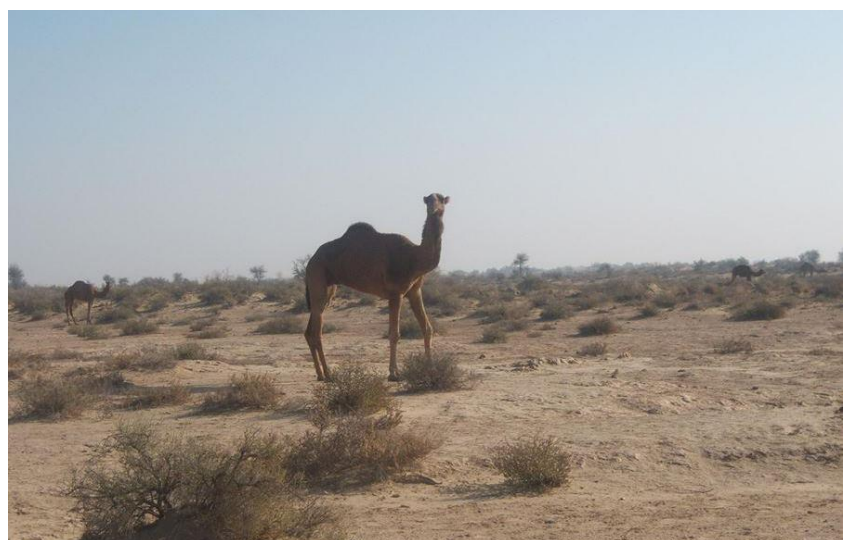

Figure 4: Camels dealing with common shrubs of the area, a natural inhabitants in cholistan.

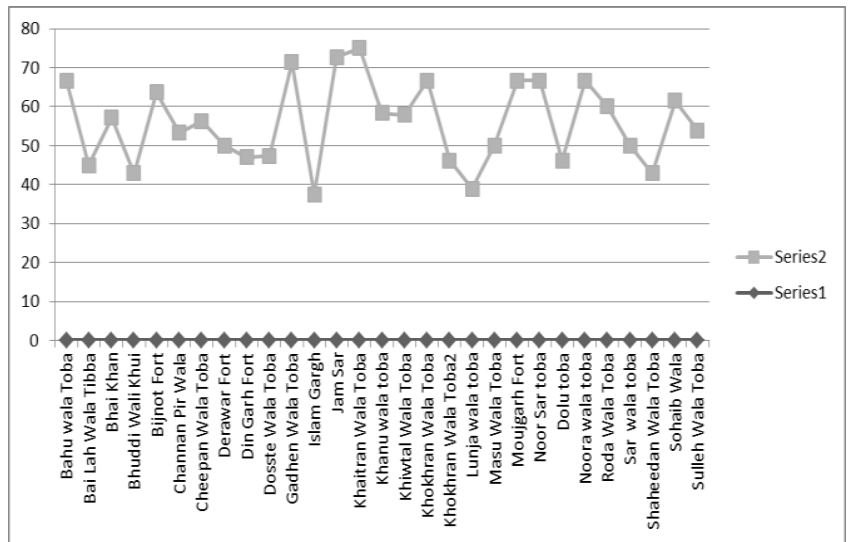

Graph 1: Comparison of mean prevalence of ectoparasites in camels at various tobas of Cholistan.

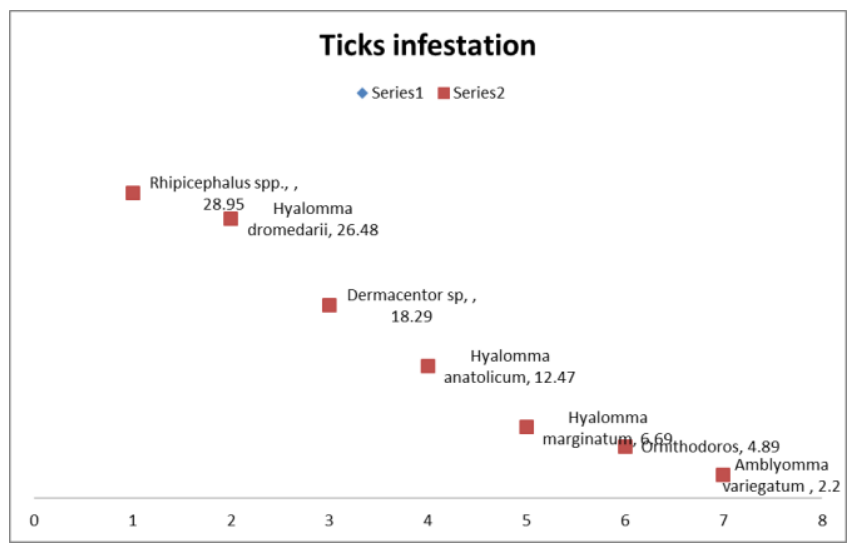

Graph 2: Ticks infestation in accordance if prevalence.

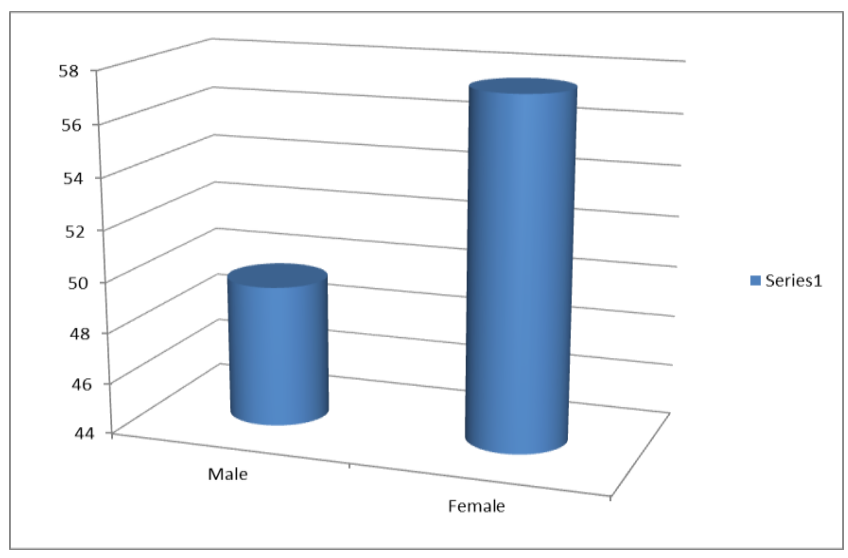

Graph 3: Preference of ectoparasites in sex-wise ratio in camels.

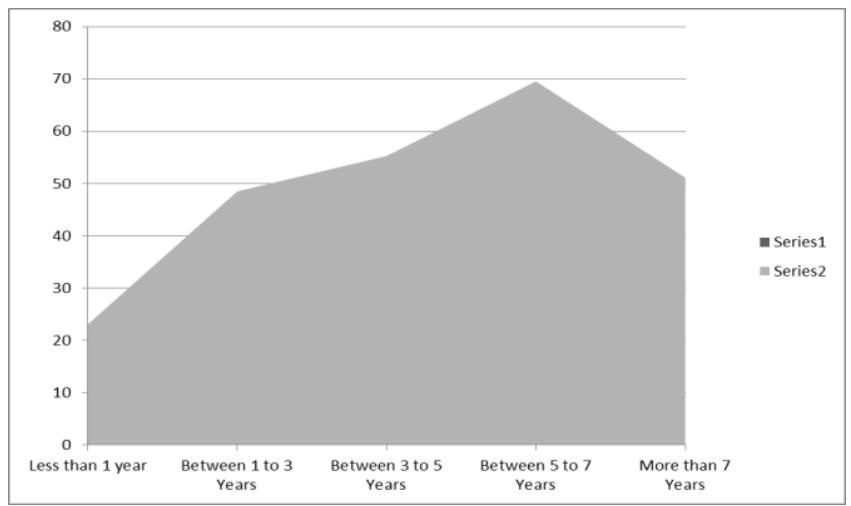

Graph 4: Age-wise pevalence and infestation of ectoparasites.

\section{References}

1. Meiloud GM, Ould Bouraya IN, Samb A, Houmeida A. Composition of mauritanian camel milk: results of first study. Int J Agric Biol. 2011;13:145-147.

2. Ali I, Chaudhry MS, Farooq U. Camel rearing in Cholistan desert of Pakistan, Pak Vet J. 2009;29(2):85-92.

3. Farooq U, Samad HA, Sher FM, Khan M.A. Cholistan and Cholistani breed of cattle. Pak Vet J. 2010;30(2):126-130.

4. Kakar AR, de Verdier K, Younas M. Rapid change of strategy is necessary for development of dromedary camel pastoralism in the Cholistan desert of Pakistan. Pastoralism Res Policy Pract. 2011;1:3.

5. Higgins AJ. Common ectoparasites of the camel and their control. Br Vet J. 1985;141:197-215.

6. Khan AD, Akram M, Abdullah M. Rainwater harvesting in Cholistan desert. Proc. National Seminar on Water Resources Development and its Management in the Arid Areas. Quetta, Pakistan. 1990;pp:59-80.

7. Baig M, Shabbir M, Akram M, Hassan M, Amjad M. Possibilities for range development in Cholistan desert as reflected by its physiography and soils. Pak J Forestry.1980;12(3):61-71.

8. Gray JS, Potgieter FT. Studies on the infectivity of Boophilus decoloratus males and larvae infected with Babesia bigemina. Onderstepoort J Vet Res1982;49:1-2.

9. Gosh SG, Bansal C, Gupta SC, Ray D, Khan MQ. H. Arched M, 
Shahiduzzaman, U, Ahmed JS. Status of tick distribution in Bangladesh, India and Pakistan. Parasitol Res. 2007;101:207-216.

10. Perry BD, Randolph TF, McDermott JJ, Sones KR, Thornton PK. Investing in animal health research to alleviate poverty. Intern Livest Res Institute (ILRI), Nairobi, Kenya. 2002.

11. Jongejan F, Uilenberg G. The global importance of ticks. Parasitol. 2004;129:1-12.

12. Biswas $\mathrm{S}$. Role of veterinarians in the care and management during harvest of skin in livestock species. In: Proc. National Seminar on Lather Industry in Today's Perspective, Kolkata, India. 2003;pp:6264.

13. Garcia Z. Integrated control of Boophilus microplus in cattle. In: Proc. 11th Int. Congr. Int. Society for Animal Hygiene, Mexico city, Mexico. 2003.

14. Ghosh SP, Yadav MP. Upcoming and future strategies of tick control: a review. J Vect Borne Di. 2007;44:79-89.

15. Parsani HR, Veer S, Momin RR, Common Parasitic Diseases of Camel. Veterinary World. 2008;1(10):317-318.

16. Hadani A, Ziv M, Rechav Y, A laboratory study of tick repellents. Entomol Exp Appl. 1977;22:53-59

17. Rust MK. Dryden MW. The biology, ecology, and management of the cat flea. Annu Rev Entomol. 1997;42:451-473.

18. Urquhart GM, Armour J, Duncan JL, Dunn AM, Jennings FW. Veterinary Parsitology, $2^{\text {nd }}$ ed. Longman Scientific and Techical, UK. 1997.

19. Bowman DD. Georges' Parasitology for Veterinarians, $7^{\text {th }}$ ed., W. B. Saunders Com. 1999; pp: 29-35, 38-39, 46-53, 61-62, 294.

20. Hendrix CM. Diagnostic Veterinary Medicine, 2nd ed., Mosby Publication. Ltd. 1998; pp:200-201, 221-226, 275-276.

21. Wall R, Shearer D. Veterinary Ectoparasites: Biology, Pathology and Control. $2^{\text {nd }}$ ed., Blackwell Science. 2001;pp:1-2, 27-31, 66, 76, 8081, 149-150, 166-167, 172-177, 179-181.

22. Walker AR, Holak IG, Prestonn PM. Ticks of domestic animals in Africa: A guide to identification of species. Bioscience. 2003: 1-221
23. Soulsby EJL. Helminths, Arthropodes and Protozoa of Domesticated Animals. 7th Ed., Bailliere Tindall, London, UK. 1982.

24. Yakchali $\mathrm{H}$. Prevalence and ectoparasites fauna of sheep and goat flocks in Iran. Veterinarski Arhiv. 2006;76(5):431-442.

25. Segerman J, Siphonaperta of Southern Africa. Handbook for the Identification of Fleas. Publication of the South African Institute for Medical Research, Johanesburg, South Africa. 1995.

26. Traub R, Co-evolution of fleas and mammals. In: Kim, K.C. (Ed.), Co-evolution of Parasitic Arthropods and Mammals.Wiley, New York. 1985.

27. Dinka A, Eyerusalem B, Yacob HT. A study on major ectoparasites of camel in and around Dire Dawa, Eastern Ethiopia. Revue Med Vet. 2010;161(11):498-501

28. Chap TLe. Introductory Biostatistics, Published by John Wiley \& Sons, Inc., Hoboken, New Jersey. Published simultaneously in Canada. 2003.

29. Rewatkar SG, Deshmukh SS, Deshkar SK, Maske DK, Jumde PD, Bhangale GN. Gastrointestinal helminths in migratory Camel. Veterinary World, 2009;2(7):258

30. Tesfaheywet ZS, Onu SH. Prevalence of ectoparasite infestations of cattle in Bench Maji zone, Southwest Ethiopia. Vet World. 2013;6(6):291-294.

31. Oryan A, Valinezhad A, Moraveji M. Prevalence and pathology of camel nasal myiasis in eastern areas of Iran. Tropical Biomedicine. 2008;25(1):30-36.

32. Hussain MH, Habasha FG, MK Faraj. Demodectic mange in Iraqi camels. AL-Qadisiya J Vet Med Sci. 2012;11(1):1-5.

33. Lawal MD, Ameh IG, Ahmed A. Some ectoparasites of Camelus dremedarius in Sokoto, Nigeria. J Entomol. 2007; 4(2):143-148.

34. Champour M, Mohammadi G, Chinikar S, Razmi G, Mostafavi E, Jalali T. Frequency of hard-tick and the influence of age and sex of camel on ticks infestation rates in one-humped camel (Camelus dromedaries) population in northeast of Iran. Sci Parasitol. 2013;14(2):89-93. 